\title{
The Quality of Life for Employees in Romania and Hungary, according to Academic and Business Journals in these Countries
}

\author{
Cristina Leovaridis
}

National School of Political and Administrative Studies, Bucharest, Romania

\begin{abstract}
This paper aims to present the quality of life for employees in Romania and Hungary, emphasizing that of the highly qualified employees, according to some academic and business journals in these two countries. The research methodology consisted of a content analysis performed on six Romanian economic scientific and business journals, three printed and three online, and also on two Hungarian economic journals, one business printed and one scientific online. The content analysis grid included criteria such as different dimensions regarding the quality of life for employees, the key terms (ideas, phrases) most used for each dimension separately etc. The period for journals content analysis was between 1 January 2009 and 30 June 2011. The paper contains a case study for each journal, including the abstracts of the most relevant articles on the research theme. Concluding, we identified many similarities between Romanian and Hungarian journals analysed, the most important is that in all journals the aspects of quality of life for employees are rarely approached; in addition, the complaints specific to knowledge workers, regarding work intensity, overload, management style, work-life balance etc., are found only as an exception. On the other hand, the articles' authors insist on subjects relevant for the economic crisis: decreases of wages, dismissals etc.
\end{abstract}

Keywords: quality of life, highly qualified employees, academic and business economic journals.

\section{Introduction}

In the literature, many authors insist on the term "knowledge economy", on the central role of knowledge in production and competition. More important than the knowledge contained in equipment, is the knowledge of the employees' mind, shared and developed by them, which are the engine of the new type of economy (Mehaut, 2008). Therefore there is a great interest is for competitive advantage that knowledge held by high-skilled employees (knowledge workers) can provide to organizations, and hence the concern for life quality of highskilled employees. Regarding the new trends of economic development, some researchers propose to use the term "learning economy" instead of widespread general "knowledgebased economy" (Nielsen and Lundvall, 2007).

Most high-skilled employees are working in the service sector; some researchers name this historic change in the structure of economic activities (services sector growth in the detriment of industry) that the "service sector revolution" (Mako and others, 2011). This sector covers a wide range of activities, from low-paid jobs ("McJobs") to the highly paid and creative, held by "knowledge workers" (Mako and others, 2009).

Copyright (C) 2012 Cristina Leovaridis. This is an open access article distributed under the Creative Commons Attribution License unported 3.0, which permits unrestricted use, distribution, and reproduction in any medium, provided that original work is properly cited. Contact author: Cristina Leovaridis E-mail: leovaridis@yahoo.com 
An employee in knowledge domain (a knowledge worker) is that who "make personal and corporate experience in knowledge, by attracting, evaluating, applying, sharing and disseminating it within the organization to solve specific problems or create value" (Sornlertlamvanich, 2011). Knowledge-intensive work requires creative solving problem and abstract thinking. Knowledge-intensive companies include services in IT, R\&D, training, educational, financial, advertising, environmental etc. Organizational culture should emphasize development and innovation creation; flat hierarchy and flexible networks increase innovation and creativity (Haataja, 2005).

The interest in improving quality of employees' life, including highly qualified, is a part of the larger issue of the social dimension of sustainability, which includes a democratization of relationships inside organizations, the latter not just being limited to merely giving autonomy and consulting with employees before making top decisions, but also referring to centring the organization's interests on the individual/employee (Leovaridis, 2010). The new type of management begins by changing its vision on and attitude towards the individual. It does not simply refer to using the individual more as a means, but it focuses on approaching the individual as a goal in itself, the supreme goal, and attempts to see what can and should the organization do in order to help the individual achieve human accomplishment throughout his work (Hoffman, 2004). The quality of working conditions became the central focus of the European social model, as its development is centred on multiple dimensions, intended to lead to a balance between flexibility and security, particularly to work satisfaction generated by salary levels, safety at workplace and harmonising professional life with private life (Consiliul European, 2008). Research performed by Eurofound showed that most Europeans, despite their countries of origin, have similar ideas on what life quality means - one of the most important factors is ensuring good working conditions at their workplace (Eurofund, 2004).

The theme of improving working conditions was developed in the last ten years in some official European documents, such as Community Strategy on health and safety at work 2002-2006 (European Commission, 2002), Community Strategy on health and safety at work 2007-2012 etc. (Comisia Europeană, 2007). The second states that, despite progress in recent years (in the lower rate of fatal work accidents in the EU), some types of occupational illnesses (musculoskeletal disorders, disorders related to psychological stress) develop. Nature of occupational risks changes due to pace of innovation and transforming nature of the work. Research in recent years on working conditions in Europe have shown a trend of increased incidence of psychological disorders, which underlies health problems at work, especially in non-manual employees (Commission Europe, 2007). Today the main new diseases and occupational risks as stress, depression, anxiety, workplace violence, harassment and intimidation, which are responsible for $18 \%$ of health problems at work, one quarter of them resulting in two weeks or more of absence from work. These problems are twice as common in highskilled employees in education, health (Leovaridis, 2011).

\section{Research Methodology}

After a preliminary documentation, we set that the period that we will use for the content analysis to be between $1^{\text {st }}$ January $2009-30^{\text {th }}$ June 2011 (2 years and a half). The content analysis will present the economic press coverage of life quality of employees in general and especially those with non-manual occupations within economic sectors specific for the knowledge society. 
In order to outline a more complete and balanced picture of the Romanian economic press on the subject concerned, selected economic publications on which the content analysis will be applied, will be both science and business, print and online: two online journals (Management\&Marketing and Petroleum-Gas University of Ploiesti Bulletin. Economic Sciences Series); one scientific printed journal (Amfiteatru Economic); two business printed magazines (Capital, Biz); one online business magazine (Cariere).

Based on consultation on a few numbers in each of the selected publications and also on theoretical information acquired previously, we identified significant dimensions for research topic, developing thus the research tool - the content analysis grid. We read all editions of publications contained in the settled time interval ( $1^{\text {st }}$ January $2009-30^{\text {th }}$ June 2011); within them, we analyzed through content analysis grid all significant articles (by title) for the topic.
In the external postdoctoral training period, conducted in Hungary $\left(1^{\text {st }}\right.$ August to $30^{\text {th }}$ October 2011), we elaborated a content analysis on two English-language economic journals in Hungary, for the same time period used for Romanian journals: one scientific online journal (Budapest Working Papers on the Labour Market); one business printed magazine (Budapest Business Journal).

\section{Research Results}

\section{A Synthetic Overview on Analyzed Journals}

The analysis (based on content analysis grid) will consider geopolitical area covered by published articles, the concrete dimension regarding the working conditions, the material type, the key terms (ideas, phrases) the most common used for each dimension separately, the usefulness of the article for the topic etc. Below we present a synthesis on few of the directions listed.

Table 1. Distribution of Articles in the Romanian and Hungarian Publications

\begin{tabular}{|c|c|c|c|}
\hline The journal & $\begin{array}{c}\text { Number of } \\
\text { issues }\end{array}$ & $\begin{array}{c}\text { Number of articles on } \\
\text { working conditions }\end{array}$ & $\begin{array}{c}\text { Number of } \\
\text { articles/issue }\end{array}$ \\
\hline Management\&Marketing & 5 & 15 & 3 \\
\hline $\begin{array}{c}\text { Petroleum-Gas University of Ploiesti } \\
\text { Bulletin. Economic Sciences Series }\end{array}$ & 10 & 18 & 1,8 \\
\hline Amfiteatru Economic & 6 & 11 & 1,83 \\
\hline Capital & 130 & 83 & 0,63 \\
\hline Biz & 43 & 66 & 2,53 \\
\hline Cariere & 30 & 71 & 1,17 \\
\hline Budapest Working Papers on the & 224 & 18 & 0,72 \\
\hline Labour Market & 25 & 14 & 1,27 \\
\hline Budapest Business Journal & 11 & 32 & 0,88 \\
\hline Total Hungarian journals & 36 & & \\
\hline
\end{tabular}

Regarding the distribution of the analyzed articles in the six Romanian publications (as indicator "no. articles / issue"), there is a relatively uniform distribution (between 0.6 and 3 articles / issue), regardless of their specific (scientific or business) or presentation (printed or online). The same can be said about the two Hungarian journals analyzed.
About the distribution of articles in Romanian journals analyzed, according to geopolitical area covered, the data show that (except PGU Ploiesti Bulletin in which a number of authors from countries outside the EU publishes studies on the labor market situation in their countries and so we find here a relatively more articles from "other countries"), in all journals predominate 
articles dedicated to working conditions in Romania (74.2\%), the few articles consider the working conditions in the EU $(17 \%)$ or very low ones for other countries outside the EU $(8.7 \%)$.

The Hungarian periodicals, as the Romanian, are overwhelmingly dominated by articles dedicated to working conditions in Hungary
$(81.2 \%)$, very few articles on the situation in the EU or outside. (Regarding the Hungarian journals, for reasons of accessibility, in the January 2009-June 2011, we read issues from two months at the beginning of the period, two at the final and two in the middle: journals in January-February 2009, MarchApril 2010 and May-June 2011).

Table 2. Distribution of Articles in the Romanian and Hungarian Publications, Depending on Approaching the Situation on the Whole / in Particular

\begin{tabular}{|c|c|c|c|}
\hline Publication & $\begin{array}{c}\text { The situation } \\
\text { on the whole }\end{array}$ & $\begin{array}{c}\text { The situation in } \\
\text { particular organizations }\end{array}$ & $\begin{array}{c}\text { No. } \\
\text { articles }\end{array}$ \\
\hline Management\&Marketing & 10 & 5 & 15 \\
\hline $\begin{array}{c}\text { PGU Ploiesti Bulletin. Economic } \\
\text { Sciences Series }\end{array}$ & 6 & 12 & 18 \\
\hline Amfiteatru Economic & 9 & 2 & 11 \\
\hline Capital & 65 & 18 & 83 \\
\hline Biz & 45 & 21 & 66 \\
\hline Cariere & 58 & 13 & 71 \\
\hline Budapest Working Papers on the & 193 & 71 & 264 \\
\hline Labour Market & 18 & 0 & 18 \\
\hline Budapest Business Journal & 6 & 8 & 32 \\
\hline Total Hungarian journals & 24 & 8 & \\
\hline
\end{tabular}

Regarding the distribution of articles in Romanian journals analyzed, depending on the approach the whole problem / private organizations, we see that, overall, it dominates the articles dedicated to the whole problem (73.1\%), similar situation also found for each publication in part, except PGU Ploiesti Bulletin (where we find a higher proportion of articles dedicated to private organizations).

In Hungarian journals, we meet the same situation on the whole, most articles are dedicated to macro analysis, but in the Budapest Business Journal is giving increased attention to particular cases, successful cases in different companies. 
5 Journal of Eastern Europe Research in Business \& Economics

Table 3. Distribution of Articles by Items on Working Conditions, in Romanian and Hungarian Journals

\begin{tabular}{|c|c|c|c|c|c|c|c|c|c|c|}
\hline & $\begin{array}{c}\text { Mana- } \\
\text { gement \& } \\
\text { Mar-keting }\end{array}$ & $\begin{array}{l}\text { PGU Plo- } \\
\text { iesti } \\
\text { Bulletin }\end{array}$ & $\begin{array}{l}\text { Amfiteatru } \\
\text { Econo-mic }\end{array}$ & Capi-tal & $\mathrm{Biz}$ & Carie-re & Total & $\begin{array}{l}\text { Budapest } \\
\text { Working } \\
\text { Papers... }\end{array}$ & $\begin{array}{c}\text { Buda-pest } \\
\text { Bu-siness } \\
\text { Journal }\end{array}$ & Total \\
\hline $\begin{array}{c}\text { Work } \\
\text { intensity }\end{array}$ & 1 & 2 & 0 & 1 & 1 & 6 & 11 & 0 & 0 & 0 \\
\hline Work program & 1 & 0 & 0 & 0 & 0 & 4 & 5 & 0 & 0 & 0 \\
\hline Job security & 0 & 0 & 0 & 14 & 2 & 2 & 18 & 1 & 5 & 6 \\
\hline $\begin{array}{l}\text { Physical } \\
\text { factors at } \\
\text { work }\end{array}$ & 0 & 0 & 0 & 0 & 0 & 1 & 1 & 0 & 0 & 0 \\
\hline $\begin{array}{c}\text { Cognitive } \\
\text { factors, nature } \\
\text { of work }\end{array}$ & 0 & 1 & 2 & 0 & 0 & 1 & 4 & 0 & 0 & 0 \\
\hline $\begin{array}{l}\text { Psychoso-cial } \\
\text { factors }\end{array}$ & 0 & 0 & 0 & 1 & 1 & 1 & 3 & 0 & 0 & 0 \\
\hline $\begin{array}{c}\text { Health at } \\
\text { workplace }\end{array}$ & 0 & 0 & 0 & 1 & 0 & 3 & 4 & 0 & 1 & 1 \\
\hline $\begin{array}{c}\text { Training, } \\
\text { professio-nal } \\
\text { develop-ment } \\
\text { and career } \\
\text { prospects }\end{array}$ & 2 & 2 & 6 & 4 & 9 & 2 & 25 & 5 & 1 & 6 \\
\hline $\begin{array}{c}\text { Work } \\
\text { organiza-tion, } \\
\text { mana-gement } \\
\text { style, decision } \\
\text { making, } \\
\text { coordina-tion } \\
\text { teams } \\
\end{array}$ & 1 & 1 & 2 & 0 & 17 & 12 & 33 & 0 & 1 & 1 \\
\hline $\begin{array}{c}\text { Social } \\
\text { relation-ships } \\
\text { (with } \\
\text { colleaguessup } \\
\text { eriors). } \\
\text { Motiva-tion, } \\
\text { loyalty, } \\
\text { assess-ment, } \\
\text { culture and } \\
\text { communi- } \\
\text { cation. HR } \\
\text { dept. activity } \\
\end{array}$ & 5 & 4 & 0 & 6 & 13 & 17 & 45 & 0 & 1 & 1 \\
\hline $\begin{array}{l}\text { Profe-ssional } \\
\text { satisfac-tion }\end{array}$ & 2 & 2 & 0 & 18 & 8 & 8 & 38 & 7 & 0 & 7 \\
\hline $\begin{array}{l}\text { Work-life } \\
\text { balance }\end{array}$ & 1 & 1 & 0 & 2 & 4 & 4 & 12 & 0 & 2 & 2 \\
\hline $\begin{array}{c}\text { Violence, } \\
\text { harass-ment, } \\
\text { discrimi- } \\
\text { nation }\end{array}$ & 0 & 1 & 0 & 0 & 1 & 0 & 2 & 0 & 0 & 0 \\
\hline $\begin{array}{c}\text { Social } \\
\text { dialogue, } \\
\text { labour } \\
\text { legislation }\end{array}$ & 0 & 2 & 1 & 11 & 1 & 6 & 21 & 0 & 0 & 0 \\
\hline $\begin{array}{l}\text { Macro context } \\
\text { of labor, } \\
\text { employ-ment, } \\
\text { recruit-ment }\end{array}$ & 2 & 2 & 0 & 24 & 9 & 4 & 41 & 5 & 3 & 8 \\
\hline No. of articles & 15 & 18 & 11 & 83 & 66 & 71 & 264 & 18 & 14 & 32 \\
\hline
\end{tabular}


Regarding the distribution of articles in Romanian journals on these dimensions, there is a predominance of articles in the dimension "social relations (with colleagues, superiors). Motivation, loyalty, evaluation, organizational culture and communication. HR department activity"- 45 articles (17\%), followed in order of frequency by articles within dimensions "macroeconomic context of work, employment, recruitment" (15.5\%), "professional satisfaction" (14.3\%), "work organization, management style, decision making, coordination teams" (12.5\%), "training, professional development, career prospects" (9.4\%) and "social dialogue, labor law" (7.9\%). Note the dimensions of which were found very few articles (under 5) such as "cognitive factors, nature of work" and "health at work" (by 4 items), "psychosocial factors" (3 articles), "violence, harassment and discrimination" (2) or "physical factors at work" (1).

In Hungarian periodicals, we find a predominance of articles within dimension "Macroeconomic context of work, employment, recruitment" (25\%), followed in descending order of frequency, of articles related to dimensions "professional satisfaction" (21,8\%), "training, professional development" and "job security" (by 18.7\%). In the other dimensions, were identified very few articles (by 2, 1 or no). We note that the journals of the two countries are about the same themes (dimensions) that are given great attention.

Another criterion we might consider is the material type, the author's position on the analyzed problem. From this point of view, in all six Romanian journals, the author's attitude is a critical one (82 articles - $31 \%$ ) or neutral (81 articles - 30\%), only in 38 articles (14\% of total) the attitude is appreciative.

In comparison, in Hungarian periodicals, we identify the author's position as the most mixed (with both critical and appreciative elements, $62.5 \%$ ), followed far from articles with a critical author's view (15.6\%), neutral (only 3 articles) or appreciative (only 2 items).

Regarding the share of items recommended to be read in Romanian journals, of all articles considered (by their title) significant for our research theme, we find that the largest share of items whose content is relevant enough to be recommended for reading is found in scientific journals (where the issue of working conditions is covered in depth), as opposed to business journals, in which even if initially, by their title, articles chosen for reading announced an interesting content, after reading we noted less profound treatment of subject, so later they were included as "not recommended to be read" or "not necessarily" (in Biz 34.8\%, in Capital 16.8\%, PGU Ploiesti Bulletin - 72.2\%, Management \& Marketing - 53.3\%, Amfiteatru Economic - 54.5\%, Cariere - 26.7\% of the articles "are recommended to be read").

The situation is opposite in Hungarian journals analyzed: in the scientific journal Budapest Working Papers on the Labour Market, 33\% of articles originally retained considered significant by title for research topic "are recommended to be read", while in Budapest Business Journal - 92.8\%.

\section{Case Studies on Romanian Economic Journals}

$\underline{B i z}$ ("the magazine of new trends in business", as reveals itself on the cover) is a magazine of "business lifestyle", nationally circulated, which appears twice a month. The journal is published in Romanian. All numbers of $\mathrm{Biz}$ in the interval $1^{\text {st }}$ January $2009-30^{\text {th }}$ June 2011 have been consulted, representing 43 issues; content analysis grid was applied on items of interest for research topic. 
Among the articles "recommended to be read" (23), we will present below some of their summaries. Thus, several articles are dedicated to good practices cases of managers leading organizations successful in media, marketing, advertising, IT and focusing on employee autonomy, team freedom, encouraging creativity etc.: for example, in the article "We are not bitter, we compete relaxed" (no. 215), a group communication manager states that "we hire people smarter than us, give them freedom"; also manager of an advertising agency states that "team is the added value and we must protect as much". Also in the article "At Google nobody hold an idea" (no. 200), it is mentioned, regarding the organizational culture focused on encouraging employees creativity: "we tried to avoid the classic pyramid structure and strict specialization. Like mad scientists in a laboratory, we like to experience". Managers of other companies propose as a solution for non-financial motivation of employees, the empowerment, aiming "to balance individual freedoms with the control exercised by managers, thus recognizing that each employee is not just an executant, but a competent decisional factor. The main advantage is establishment of a mobilizing atmosphere, which favours the appearance of belonging and initiative" ("Delegation to delegation" article, no. 186).

Capital is a newspaper in "economic and financial" category, nationally circulated, published weekly, in Romanian. We consulted all newspapers in the research interval, representing 130 issues.

Among the items "recommended to be read" (14) some are more relevant ideational, both in content and title, we present some of their summaries. The topic of companies concern for employees health appears in the article "Why companies want their employees have muscles" (no. 22/2009): "for every RON spent on employees' health, the company earns three. In Romania, in 2009, only $15 \%$ of companies excluded from the benefits the subscriptions at gym (fitness, swimming, aerobics); the biggest advantage of sport is a positive impact on the psyche, the improving of employee's physical condition, but also the socialization with colleagues or with employees of other companies". Often approached is the topic of layoffs or cuts in salaries and bonuses in Romanian companies during the crisis, with many articles with suggestive headlines: "Lost your job at patron? Be a cop!” (no. 8/2009), "The labor market remains frozen until the summer" (no. 10/2009), "What do you prefer, door or sacrifice curve?" (no. 5 / 2009), "Cynicism of labor market: master and faculty profile have no value" (no. 3/2011), "Managers heads fallen under the crisis sword" (no. 40/2010), "Unemployment remained the characteristic of firms private also in 2010" (no. 46/2010) etc. There are also cost-saving alternative, not involving employees dismissal: thus, in the article "What to do when you get tired to hire people" (no. 2/2010), it states that as alternatives to staff cuts, companies have used in 2010: salaries reduces, bonuses cuts (no trainings, teambuildings, the holiday presents, subscriptions to gyms or catering services), unpaid forced leave, eliminating bonuses for overtime or their compensation with time off, the payment form other than book work (so the company pays no social security). Employees are demotivated especially if their basic needs are met by reducing wages, but will be less disappointed if the budget for training, coaching etc. will be cut.

A topic rarely approached is the work-time balance: in the article "Work at home, incentive for employees in crisis times" (no. $6 / 2010$ ) the authors start from the fact that of the 100 companies for which Americans want to work, 14 have subsidiaries in Romania, one of the benefits offered to employees are working from home (in SAS, Cisco): employee is satisfied with flexibility, and employer may give him more work, he delivering it "from everywhere he is".

PGU Ploiesti Bulletin. Economic Sciences $\underline{\text { Series }}$ is a quarterly academic journal (4 issues yearly), written in English, indexed in IDB, published by Petroleum-Gas University 
Ploiești. We consulted all journals in the analysis interval, representing 10 issues.

There are some articles (13) "recommended to be read", some of their summaries will be presented below. In the article "Adapting labour market institutions to the new economy challenges", published in number $2 / 2009$, the author emphasizes the idea that due to the expansion of ICT use, there were changes on the labor market, including legislation, to increase the adaptability of workforce and companies in a changing and competitive environment, which led to the development of teleworking; but this has as disadvantage the decreasing of union power. The author emphasizes the need of some policies on the labor market taking into account the nature of cognitive labor, such jobs have an increasingly share. A form of teleworking can be the homework, theme developed in the article "Homework - an expression of flexi-security of work relations", in the number 4/2009 whose author presents the advantages and disadvantages of the homework compared to classical work done at the employer and the legislation in different European countries on this type of work. A lot of significant articles related to the research topic refer to stress at work, particularly for professional employees with non-manual occupations: in the article "An empirical study on the burnout of IT professionals employed for Middle East countries", published in issue $4 / 2009$, the authors present a survey by questionnaire applied to 160 IT employees in Singapore, Malaysia and Thailand, about the causes of burnout and effects of stress on employees, in relation to interpersonal relations at work, employees' loyalty, satisfaction with job, health problems caused by stress. The research revealed that stress has serious negative consequences, such as job dissatisfaction, deteriorating relationships with colleagues and family, mental and physical diseases, performance decreasing.

The Management \& Marketing is a biannual scientific journal, IDB indexed, edited by the
Faculty of Economics and Business Management, University of Craiova. All articles are published in English. We consulted all journals in the analysis interval, representing 5 issues.

There are several articles (8), which are very substantial in ideas and "recommended to be read"; we'll present their summaries. The article "New patters in scheduling working time" focuses on increasing employee work performance: authors analyse working time in a company, in relation to employee life cycle and indicate the necessity to implement flexible work schedules in certain periods of life, in order to achieve work-life balance, increased satisfaction and employee performance. Employee performance and loyalty are essential elements, especially in companies providing services, such as advertising agencies, topic developed in the article "Human resources management in advertising agency", issue $1 / 2009$, in which the author, after interviews with the managers of several Romanian advertising agencies, shows the necessity to use, in organizations based on professionals' competences and creativity, a human resources management based on employees, on their satisfaction and motivation.

Amfiteatru Economic is also a biannual scientific journal, is graded ISI, IDB indexed and edited by the Faculty of Commerce of the Academy of Economic Studies, Bucharest. All articles are published in English. All necessary issues (6), in analysis interval, have been consulted.

There are some articles (6) very rich in ideas, "recommended for reading" and we shall briefly discuss their topics in the following paragraphs. A topic relevant to our research, included in this journal articles is that of employee protection, as part of the corporate social responsibility of companies, topic stressed in the article "Social responsibility practices regarding facilities granted to employees and consumer protection in selected European companies" (issue 29/February 2011). Articles present some of 
the types of RSC by facilities given to employees in the 13 biggest European companies (based on the market capitalization criterion):

- Employee representation in supervising teams, trade unions and work councils - at Allianz, GDF Suez, Daimler, Nestle (the latter even organizes manager trainings on the ILO norms);

- Equal opportunities in employment - at Bayer men and women receive equal wages (based on professional abilities) and $4,3 \%$ of employees are persons with disabilities; Tesco has no retirement age, there are 70-80 years old employees;

- Benefits for employees: a profit share for loyal employees, health and pension insurances at GDF Suez; HSBC has a telephone helpline in order to counsel employees having various financial problems; Roche Holding offers health checks and free access to private healthcare services for employees, including fitness centres, swimming pools, healthy eating programs and relaxation; Siemens emphasizes the need of harmonising work and private life - by offering flexible schedules, part-time work, teleworking, a kindergarten near company headquarters, children's programs on holidays, paediatrics' services and afterschool facilities;

- Professional development: promoting their own employees (and not recruiting outside employees) at Allianz; in Tesco - training employees who wish to get promotions;

- Workplace health and safety - BHP Billiton intends to eliminate healthcare risks by regularly controlling workplace exposure to noise, radiation, vibrations, tiredness etc., and by offering protection equipment; GDF Suez trains its employees on workplace healthcare, safety, psychological risk control;
- Ethics and communication: Roche Holding has a standard procedure on solving ethical dilemmas that employees might be confronted with at the workplace and provides online training to solve employee ethical problems; Vodafone measures on a regular basis through questionnaires the employee involvement degree towards the organization, as well their desire to work with them.

Cariere. (Leadership Journal) is a business magazine ("business lifestyle"), nationally available, on a monthly basis, published in Romania. All issues between $1^{\text {st }}$ January 2009-30th June 2011 (30 issues) have been analysed.

19 articles were highly substantial in ideas, "recommended to be read". We'll present their summaries below. The topic of effects of workplace overloads on employee health was found in the following articles. The article "One in three Romanians has work-related palpitations" (october 2010) presents the data from a ICCV survey, according to which a third of Romanian employees claim to have experienced palpitations or high blood pressure because of work, while half of them complain of headaches or anxiety and stress. The biggest number of employees experiencing workplace palpitations is of those working in Bucharest (44\% compared to $30 \%$ of those in the Centre Region). Women, rather than men, tend to experience more tension and the associated physical symptoms, such as insomnia, stomachaches, headaches, high blood pressure, tiredness and anxiety. Although, women are considered not to drink more alcohol or smoke more on account of work tensions. Employees in larger companies stated that they experienced more physical and behavioural symptoms associated with workplace stress rather than smaller companies employees.

The article "Over $40 \%$ of Romanian employees experience back pains because of 
work conditions" ( $3^{\text {rd }}$ May 2011) shows that approximately $22 \%$ of absence days are caused by musculoskeletal disorders provoked by too much effort, while almost $42 \%$ of Romanian employees experience back pains due to working conditions, one of the highest rates of European countries. These are few conclusions of the study regarding the impact of musculoskeletal disorders on workforce conducted by the Work Foundation Organization of Great Britain. The article "Risks of professional exhaustion increase in the case of those working over 40 hours per week" $\left(30^{\text {th }}\right.$ June 2011) shows that the probability of suffering from professional exhaustion increases by six times when an employee works more than 8 hours a day, according to a survey conducted by a Spanish expert. The article "Permanent stress, the main cause of disorders experienced by journalists" ( $6^{\text {th }}$ June 2011) highlights that the main medical disorders experienced by journalists are chronic fatigue and stress-related digestive disorders $(80 \%)$, decreased biliary activity, bowel disorders, caused by unhealthy eating (50\%). These are results of a free testing campaign, organized by the Integrative Medicine Patronage in March 2011.

A comparative view of the articles in the analysed issues of the 6 Romanian journals indicate a series of both similarities and differences among them, regarding the manner of presenting topics related to employee work conditions:

- The distribution of articles by dimensions shows a greater interest of business journals for current topics such as employment, dismissals (related to workplace security), salaries - increase, decrease, stagnation (the dimension of professional satisfaction), employment (the dimension of macro context of labour), social dialogue and work legislation, professional development and training (including MBA), work organization and management style, social relations and human resources management. Although their numbers are small, the professors and researchers publishing in scientific journals approach also more recent topics, regarding work conditions of high-skilled employees, such as work intensity, work schedule, cognitive factors, work-life balance - topics rarely approached in business magazines;

- If in business magazines, the key terms most often used are: salary, labour market, employment, layoffs, MBA, training, leadership, organizational culture, loyalty, performance evaluation, motivation etc., in the scientific journals they are: occupational stress, burnout, flexi-curity, working time, innovation, knowledge management, competences, organizational learning etc.

\section{Case Studies on Hungarian Economic Journals}

Budapest Working Papers on the Labour Market is a scientific journal edited in English by the Economic Institute of the Hungarian Academy of Sciences together with the Human Resources Department of the Corvinus University in Budapest, IDB indexed, with monthly issues. For the mentioned interval, 25 issues were analysed.

6 articles are more substantial in ideas and they are "recommended to be read". An article centred on salary topic is "Innovation and Rent Sharing in Corporate Wage Setting in Hungary" (issue 8/2009), in which the author analyses the manner of salary calculation in innovative companies between 1998-2006, pointing out that this varies according to the economic sector, emphasizing on sharing profits with employees and additional bonuses for employees in innovative companies.

The economic crisis and its effects on labour market is another topic of interest among the journals's authors, approached in the article "Firm-level Responses to the Economic Crisis, 2008-2009" (issue 5/2010): during the 2008-2009 economic crisis, Hungarian companies combined personnel reduction 
with "softer" measures such as cutting salaries or cutting working hours, most companies preferred to stop employing rather than hiring.

Budapest Business Journal is a journal with 2 issues monthly, offering business professionals information and analyses on economic topics such as investment, finances, industry, IT, tele-communications, management and real estate, combining information from the Hungarian business community with international opinions on the matter.

13 articles proved to be more substantial in ideas, they are "recommended to be read" and some of them will be summarised below. A rarely debated topic is that of workplace healthcare, as in the article "Making staff fit for office" (3-16 th June 2011)., which presents companies strategies to preserve their employees' health (cases of good practices): Gedeon Richter offers health insurances for employees, private hospital for top management, water for drinking in offices, organizes sport events for company members, massage, membership in fitness clubs, annual medical checks for employees since 2008; Porsche Hungary offers in addition a football court and a swimming pool; Imperial Tobacco is concerned with reducing stress and attempts at maintaining a positive and optimistic atmosphere in their offices, a private hospital for medical checks; MOL claims to offer voluntary medical checks, healthy diet and counselling to quit smoking etc. through the program "Step Take a step for your health!".

The topic of flexible working arrangements is found in the article "Excuse me, mind sharing that job?" $\left(26^{\text {th }}\right.$ February-11 ${ }^{\text {th }}$ March 2010) which reminds that in Hungary only $8 \%$ of employees have flexible arrangements (parttime, job sharing, teleworking). Sharing jobs refers to 2 employees sharing the same job on a part-time basis; they interact as partners, work as a team, sharing responsibilities and a full-time salary. Budapest Bank (an example of good practice) introduced such a flexible schedule since $2002-10 \%$ of its 3000 employees work like this, especially mothers of babies - this is a manner of motivating employees, offering them the possibility of a work-life balance.

A comparative view over the articles of the analysed issues of the two Hungarian journals point out a series of differences between them, regarding the manner in which topics related to employee work conditions are presented:

- The topics approached by the academic journal emphasize aspects of salary (the dimension of professional satisfaction), but also training and the macro context of labour market (employment), while the other journal focuses more on dismissals generated by the economic crisis (the workplace security), but also on macro context of labour market and on presenting certain managers as successful examples (in this cases approaching indirectly the matter of work-life balance). In the first case, the intention is analytic and exploratory - an attempt to find connections between variables and socioeconomic indicators, explanations of labour market phenomena including the connection between labour market and school, while in the second case, the intention is to inform businessmen on current events on the Hungarian labour market - it is here that cases of good practices are invoked, including matters of improving work conditions for employees, an approach absent in the academic journals;

- The previous explanation is confirmed in the case of frequent key-terms (salary, faculty, training, employment in the first case and layoffs, unemployment, flexible arrangements, seasonal work etc. in the second case).

\section{Conclusions}

A comparative view over the articles referring working conditions in Romanian and Hungarian journals indicates more 
similarities than differences between the journals of the same type, both in Romania and Hungary:

- The number of articles per edition is similar, for the journals of both countries;

- The distribution of articles inside the publications based on the geographical area to which the articles refer, shows an emphasis on the national situation in the business journals from Romania and in just one of the three Romanian academic journals, but also in the business and the academic Hungarian journals;

- The distribution of articles based on approaching the overall situation vs. particular cases in organizations shows a concentration on overall analysis in all Romanian journals (excepting $P G U$ Bulletin) and only in the Hungarian academic journal (the Hungarian business magazine emphasizes cases of good practices inside particular successful organizations);

- The approached dimensions are similar for the types of publications - current topics regarding the economic crisis in the Hungarian and Romanian business magazines (hiring, macroeconomic context) and "training and professional development" as a common dimension frequent in Romanian and Hungarian academic publications; as differences, the Hungarian business magazine presents organizations and managers as successful examples of good practices, including in the improvement of employee working conditions, while the Romanian academic journals feature in addition topics related to knowledge economy - knowledge management, innovation etc.;

- The business journals of both countries are dominated by descriptive and informative articles, while the academic journals - by analytical and theoretical articles, which is another noteworthy similarity; it is to be noted that no matter the type of journal, articles providing proposals of improving the identified situation are few in the Romanian journals and none in the Hungarian ones;

- Regarding the authors' positions, another similarity: in the Romanian and Hungarian academic journals, the mixed approach is dominant, while in the business journals, the situation is more nuanced - in the Hungarian business magazine, the distribution of articles (critical / appreciative /mixed/ neutral) is very balanced, similar only to one of the Romanian business journals (Biz); in the other two Romanian business magazines the authors' approach is mainly critical.

Concluding, in all eight Romanian and Hungarian journals analysed, the aspects of working conditions are insufficiently approached (in average of 0,6-3 articles per issue, provided the journals have a large number of pages, for instance: Capital - an average of 32 pages, Amfiteatru Economic around 350 pages, Biz - approx. 84 pages, Management\&Marketing - around 170 pages, Budapest Business Journal - 24 pages). When approached, the focus is on the socioeconomic topics relevant for the crisis such as decrease and/or stagnation of salaries, layoffs, unemployment etc.; difficulties specific to high-skilled employees' working conditions (regarding working time, work intensity, work nature, work overload, leadership style, knowledge management, work-life balance etc.) are found only as an exception.

\section{Acknowledgement}

This paper is suported by the Sectorial Operational Programme Human Resources Development (SOP HRD), financed from the European Social Fund and by the Romanian Government under the contract number SOP HRD/89/1.5/S/62988. 
13 Journal of Eastern Europe Research in Business \& Economics

\section{References}

Comisia Europeană (2007). 'Îmbunătăţirea Calităţii şi Productivităţii în Muncă: Strategia comunitară 2007-2012 privind,' sănătatea şi securitatea în muncă, Brusells.

Comisia Europeană (2010). 'Europa 2020,' O Strategie Europeană Pentru o Creștere Inteligentă, Ecologică şi Favorabilă Incluziunii. Bruxelles.

Consiliul European (2008). 'Decizia Consiliului din 15 Iulie 2008 Privind liniile Directoare Ale Politicilor de Ocupare a Forţei de Muncă Ale Statelor Membre,' Jurnalul Oficial al Uniunii Europene.

European Commission (2002). 'Communication from the Commission,' Adapting to change in work and society: a new Community strategy on health and safety at work 2002-2006, Brussels.

European Foundation for the Improvement of Living and Working Conditions Eurofound (2004). 'Changing Europe: Better work, better life. Four-year work programme 2005-2008,'

Haataja, M. J. (2005). 'Development of Competitiveness of Knowledge-Intensive Services,' Tampere University of Technology, Finland.

Hoffman, O. (2004). Sociologia Organizaţiilor. Editura Economică, București.

Leovaridis, C. (2010). 'O perspectivă Comparativă Asupra Situaţiei Sănătăţii la Locul de Muncă Pentru Angajaţii Din Ţările Uniunii Europene,' In E. Avram (coord.). Psihologia sănătății organizaționale. vol. 1. Editura Universitară, Bucuresti, 36-50.

Leovaridis, C. (2011). 'Calitatea Vieţii Angajaţilor în Ţările Membre UE. Aspecte Ce Țin De Natura şi Organizarea Muncii,' Revista Română de Sociologie 5-6, 421-436.
Mako, C., Csizmadia, P., Illessy, M., Iwasaki, I. \& Szanyi, M. (2009). Organizational Innovation in the Manufacturing Sector and the Knowledge Intensive Business Services, Institute of Economic Research, Hitotsubashi University, Tokyo.

Mako, C., Csizmadia, P., Illessy, M., Iwasaki, I. \& Szanyi, M. (2011). Organizational Innovation and Knowledge use Practice: Cross-Country Comparison (Hungarian Versus Slovak Business Service Sector), Institute of Economic Research Hitotsubashi University Tokyo.

Mehaut, P. (2008). 'Reshaping the Internal Labour Markets and Re-Articulating them to External Labour Markets: Hypothesis form the France Case,' in Grunert, H. (coord.), Good and "bad" external labour markets, Mitteilungen, 77-86.

Nielsen, P. \& Lundvall, B.- A. (2007). "Innovation, Learning Organizations and Employment Relations," in Mako, C., Moerel, H., Illessy, M., Csizmadia, P., (coord.), Working it out? The Labour Process and Employment Relations in the New Economy, Academiai Kiado, Budapest, 65-84.

Sornlertlamvanich, V. (2006). 'Managing Knowledge Workers,' in V. Sornlertlamvanich, Knowledge Management System, http://203.185.96.228/virach/sites/default/ files/paper/lecture/kms/kms-ch12.pdf, accessed at 25.05.2011.

*** Amfiteatru Economic, issues 25, 26/2009; $27,28 / 2010 ; 29,30 / 2011$.

*** Biz, issues 173-189/ 2009, 190205/2010, 206-215/2011.

*** Budapest Business Journal, issues 912/2011; 3-6/2010; 1-3/2009.

*** Budapest Working Papers on the Labour Market, issues 1-7 /2011; 1-10/2010; 18/2009. 
*** Buletinul UPG Ploieşti. Seria Ştiinţe Economice, issues 1-4/2009; 1-4/2010; 12/2011

*** Capital, issues 1-51/2009; 1-51/2010; 1 $25 / 2011$.

*** Cariere, issues 1-12/2009; 1-12/2010; 1 $6 / 2011$.

*** Management \& Marketing, issues 1/2009; 1, 1 special, $2 / 2010 ; 1 / 2011$ 